\title{
Relationship between Circulating Protein p53 and High Sensitivity C-Reactive Protein in Central Obesity Men with Inflammaging
}

\author{
Rina Triana ${ }^{1,2 *}$, Anna Meiliana ${ }^{1,2}$, Eli Halimah ${ }^{1}$, Andi Wijaya ${ }^{2}$ \\ ${ }^{1}$ Faculty of Pharmacy, Universitas Padjajaran, J1. Eijkman No.38, Bandung, Indonesia \\ ${ }^{2}$ Prodia Clinical Laboratorium, Jl. Kramat Raya No.150, Jakarta, Indonesia \\ *Corresponding author. E-mail: rina.triana@prodia.co.id
}

Received date: Feb 6, 2018; Revised date: Sep 27, 2018; Accepted date: Oct 10, 2018

\section{Abstract}

$\mathrm{B}$ ACKGROUND: The mechanism of aging goes along with age, one of which is characterized by cellular senescent, which occurs mostly in adipose tissue. Adipose tissue is the site of accumulation of large cell senescent, in the regulation of obesity and aging. Proteins p53 is marker for cell senescent, which are also known to induce inflammation. This study was aimed to determine the relationship between circulating protein p53 and high sensitivity C-reactive protein (hsCRP) in central obese men with inflammaging.

METHODS: The study design is an observational study with cross-sectional approach. The subjects were 75 central obese men (waist circumference $/ \mathrm{WC}>90 \mathrm{~cm}$ ), aged $\geq 45$ years old. Subjects were divided into 2 age groups, those are middle age group: 45-59 years old (50.7\%) and elderly group: $\geq 60$ years old (49.3\%). Examination of circulating p53 was done using enzyme-linked immunosorbent assay (ELISA) method, and the hsCRP examination was done by chemiluminescent method.

RESULTS: It was found that there was a correlation between circulating p53 and hsCRP in elderly ( $\mathrm{r}=-0.414$; $p<0.05)$ but not in middle age $(\mathrm{r}=-0.127 ; p=0.449)$.

CONCLUSION: From this study, it is assumed that more senescence cells in elderly are resulting in increased chronic inflammation.

KEYWORDS: aging, senescent, inflammaging, protein p53, hsCRP

Indones Biomed J. 2019; 11(1): 59-62

\section{Introduction}

Obesity is defined as an abnormal or excessive condition of fat accumulation in adipose tissue that may interfere with health.(1) Obesity in individuals with excess fat in the intraabdominal depot (abdomen) or central obesity is more at risk of disease due to obesity. According to the World Health Organization (WHO) criteria used by the Indonesian Basic Health Research, central obesity is expressed by the size of waist circumference $(\mathrm{WC})>90 \mathrm{~cm}$ for men or $\mathrm{WC}>80$ $\mathrm{cm}$ for women.(2) Because of hormonal differences, women who are overweight tend to have more subcutaneous adipose tissue, while overweight men show a central increase in obesity and are therefore more susceptible to metabolic complications. $(3,4)$

In obesity, there is a concept of low-grade chronic inflammation called meta-inflammation. Along with aging, the concept of low-grade chronic inflammation is known as inflammaging (inflammation and aging).(5) Cytokines such as tumor necrosis factor- $\alpha$ (TNF- $\alpha$ ) and interleukin-6 (IL-6) and acute phase proteins such as high-sensitive C Reactive Protein (hsCRP) increase in obesity.(6) Unlike other markers of inflammation, CRP levels are stable over long periods, have no diurnal variation, and can be measured inexpensively with available high-sensitivity assays.(7)

Inflammaging is caused by a senescent cell. Senescence is the cellular response to damage and stress. 
Continuous senescent cells can accelerate aging and agerelated pathology by secreting secretions, senescenceassociated secretory phenotype (SASP). Mechanically, senescent cells can cause age-related diseases because they secrete a lot of proinflammatory cytokines (which are called SASP) that can modify the environment in tissues and alter normal cell function. $(8,9)$

Adipose tissue is the site of accumulation senescent cells, in the setting of obesity and aging. Cellular senescence is irreversible, in which cells stop dividing in response to telomere shortening, oncogene activation, or metabolic stress. The senescent cell has a larger phenotype, showing the positivity associated with beta-galactosidase aging cell activity, and can secrete many chemokines, cytokines, growth factors, and metalloproteinase matrices.(10) Cell aging may contribute to age-related adipogenesis and lipodystrophy.(11)

Many stimuli can cause aging. This mechanism of aging is characterized by multiple pathways. The common aging marker consists of the mediator of the cell senescent themselves, such as p16, ADP ribosylation factors (ARF), p53, p21, p15, p27 and hypophosphorylated RB.(12) The p53 is an important mediator of cellular response to cellular aging.(13) Expression of p53 in adipose tissue increases with increasing body mass index (BMI). It increased in the fat cell fraction of subjects with diabetes whose adipocyte cells were aged.(11) Expression of p53 in visceral fat obese rats increased compared with rats whose nutrients were limited.(14) The p53 levels in the blood on the subject of central obesity not yet discovered.

After knowing the risks that can occur due to central obesity, as well as the link between obesity, aging and inflammatory processes (inflammaging), it is necessary to research the relationship between circulating protein p53 and hsCRP so that it is expected to become the basis of prevention and intervention to make early prevention strategies in individuals with central obesity.

\section{Methods}

The design of this study is an observational study with cross-sectional approach. The subjects of the study were obese adult men, age $\geq 45$ years, $\mathrm{WC}>90 \mathrm{~cm}$, which would be divided into 2 groups, based on WHO criteria: middle age: $45-59$ years old and elderly: $\geq 60$ years old.

The number of samples needed in this study is calculated by using the formula for quantitative variables by Charan and Biswas.(15) Inclusion criteria were central obese man ( $\mathrm{WC}>90 \mathrm{~cm}$ ), aged $\geq 45$ years. Exclusion criteria were liver function impairment (serum glutamic oxaloacetic transaminase (SGOT)/serum glutamic pyruvic transaminase (SGPT) $>2$ times normal value), acute infection (hsCRP> $10 \mathrm{mg} / \mathrm{L}$ ), suffering from cancer or undergoing cancer treatment (based on interview).

Subjects were selected from patients of Prodia Clinical Laboratory in Jakarta, Bogor, Bandung and Semarang, from November to December 2017. Laboratory analysis for initial screening was done at Prodia Clinical Laboratory. This protocol has been approved by the Ethics Commission of Padjadjaran University No. 1026/UN6.C.10/ PN/2017.

Materials used in this study were human serum, enzyme-linked immunosorbent assay (ELISA) assay kit for p53 (Bender MedSystems GmbH, Vienna, Austria) and hsCRP assay kit (Cat. No.\#L2KCRP2, Siemens, Cambridge, UK). Data is processed through SPSS for Windows 24.00 (SPSS Inc., Chicago, USA). For statistical tests, the significance level used is $5 \%$. Spearman correlation test was conducted for data analysis.

\section{Results}

The initial number of subjects recruited was 86 subjects. Seventy-five subjects met the inclusion and exclusion criteria, clinical and biochemical features are shown in Table 1.

Table 1. General characteristics of subjects.

\begin{tabular}{lcccc}
\hline $\begin{array}{c}\text { Characteristic } \\
(\mathbf{n}=75)\end{array}$ & Min & Max & Median & Mean \pm SD \\
\hline Age (years) & 45 & 73 & 59 & $57.49 \pm 8.09$ \\
Clinical & & & & \\
$\quad$ WC (cm) & 91 & 125 & 100 & $102.77 \pm 7.91$ \\
Biochemistry & & & & \\
$\quad$ SGOT (U/L) & 12 & 48 & 23 & $24.65 \pm 7.21$ \\
$\quad$ SGPT (U/L) & 8 & 68 & 29 & $31.88 \pm 14.36$ \\
$\quad$ hsCRP(mg/L) & 0.3 & 6.8 & 2.1 & $2.417 \pm 1.656$ \\
p53 (IU/mL) & 0.03 & 14.76 & 0.19 & $1.216 \pm 3.012$ \\
\hline
\end{tabular}

Min: minimum value; Max: maximum value; SD: standard deviation; WC: waist circumference; SGOT: serum glutamic oxaloacetic transaminase; SGPT: serum glutamic pyruvic transaminase. 
Subjects were divided according to age criteria recommended by WHO, as follow middle age: 45-59 years old (50.7\%) and elderly: 60 years and above (49.3\%). The descriptive test based on age group as shown in Table 2.

\section{Correlation of Circulating Protein p53 with Inflammatory Conditions}

To see the interaction between circulating p53 and inflammatory variable, Spearman correlation test was performed. The correlation result showed circulating Protein $\mathrm{p} 53$ correlated with hsCRP in elderly with $\mathrm{r}=-0.414$ and $p=0.011$. Meanwhile there was no correlation shown in the middle age group $(\mathrm{r}=-0.127, p=0.449)$.

\section{Discussion}

In the elderly, low-grade inflammation (inflammaging) is a risk factor for age-related diseases and physical weakness. Inflammaging is characterized by increased concentrations of proinflammatory cytokines. In he previous studies was found that proinflammatory cytokines stimulate synthesis of CRP in the liver, and its levels increase in the elderly. (16) New research conducted by Puzianowska-Kuźnicka, et al., said that hsCRP is a proinflammatory cytokine that can illustrate the risk of mortality in the subject of the elderly.(17)

This study found that circulating p53 correlates to hsCRP in elderly. As has been said before, p53 is a mediator of cell senescence where cellular senescence will be more common in elderly than middle age.(13,15) In addition, the possibility of cells becoming senescence due to the mechanism of cell damage that continues to occur on elderly. In the middle age there is no correlation between circulating p53 and hsCRP. This result may be caused by various factors. Drugs consumed by the subject (antioxidants or metformin) are known to improve aging. In the aging process, the senescent cell secretes SASP which will induce the immune system to clear senescent cells.(18) In subjects with a good immune system, the process of cleaning will work well, on the contrary if the immune system on the subject decreases, the senescent cells will accumulate more.

Inflammaging is caused by the presence of cells that are senescent. Continuous senescent cells can accelerate aging and age-related pathology by secreting SASP, it causeses age-related diseases because they secrete a lot of proinflammatory cytokines resulting in chronic inflammation. $(8,9,11)$

In this study, the negative correlation of circulating p53 and hsCRP in elderly indicates that the low concentration of $\mathrm{p} 53$ in circulation is inversely proportional to hsCRP concentration. Low levels of circulating p53 signify the senescent cells so that the possibility of p53 is more in the intracell. This is supported by high concentrations of hsCRP because senenscent cells can cause inflammation caused by SASP (Figure 1).

From the follow-up analysis it was found that in the middle-aged group with high p53 as much as $66.7 \%$ had hsCRP with an intermediate risk of $1-3 \mathrm{mg} / \mathrm{L}$. Whereas in the

Table 2. General characteristics of subject by age.

\begin{tabular}{|c|c|c|c|c|c|}
\hline \multirow{2}{*}{ Characteristic } & \multicolumn{2}{|c|}{$\begin{array}{l}\text { Middle-aged } \\
\qquad(n=38)\end{array}$} & \multicolumn{2}{|c|}{$\begin{array}{l}\text { Elderly } \\
(n=37)\end{array}$} & \multirow{2}{*}{$p$} \\
\hline & Median & Mean \pm SD & Median & Mean \pm SD & \\
\hline Age (year) & 49 & $50.53 \pm 4.29$ & 64 & $64.65 \pm 3.46$ & $0.000 *$ \\
\hline \multicolumn{6}{|l|}{ Clinical } \\
\hline $\mathrm{WC}(\mathrm{cm})$ & 100.5 & $102.45 \pm 8.18$ & 100 & $103.11 \pm 7.72$ & 0.683 \\
\hline \multicolumn{6}{|l|}{ Biochemistry } \\
\hline SGOT (U/L) & 23 & $25.55 \pm 6.46$ & 23 & $23.73 \pm 7.88$ & 0.23 \\
\hline SGPT (U/L) & 31.5 & $34.92 \pm 14.70$ & 25 & $28.76 \pm 13.48$ & $0.038^{*}$ \\
\hline hsCRP(mg/L) & 2.5 & $2.82 \pm 1.80$ & 1.6 & $2.00 \pm 1.40$ & $0.035^{*}$ \\
\hline P53 (IU/mL) & 0.19 & $1.21 \pm 3.24$ & 0.19 & $1.22 \pm 2.80$ & 0.652 \\
\hline
\end{tabular}

SD: standard deviation; WC: waist circumference; SGOT: serum glutamic oxaloacetic transaminase; SGPT: serum glutamic pyruvic transaminase; ${ }^{*} p<0.05$ (Mann Whitney). 


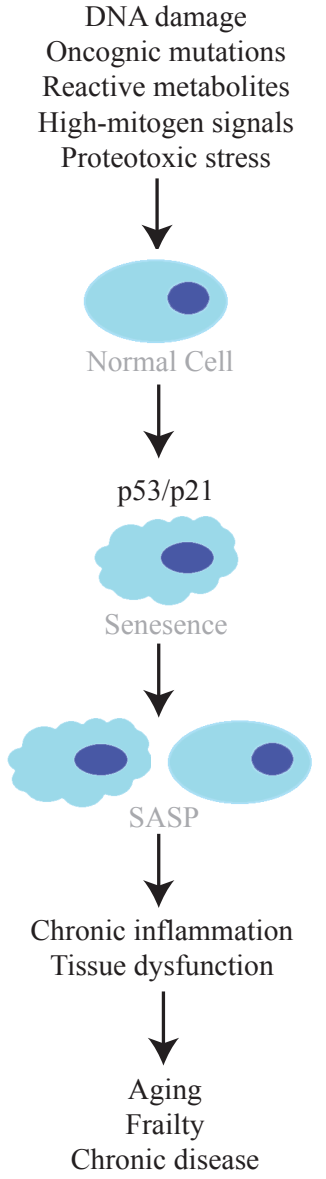

Figure 1. Inflammation caused by senescent cells.(19)

elderly group with low $\mathrm{p} 53,62.5 \%$ had high risk of hs-CRP $>3 \mathrm{mg} / \mathrm{L}$.

Limitations in this study are the difficulty of getting subjects who do not take medication. Most middle-aged and elderly subjects start taking drugs, such as anti-inflammatory, so that in this study the drug factor can be a confounding factor in the results of the study. Another limitation is that researchers excluded the subjects who suffered from cancer only from questionnaires, where there might be subjects who did not know he had cancer because the subject of cancer can affect circulating p53 protein levels.

\section{Conclusion}

Our study found a lower hsCRP level in elderly compared to the middle age subjects, due to the elderly consumption of anti-inflammatory agents. The correlation between circulating $\mathrm{p} 53$ and hsCRP in elderly, and a combination of low p53 and high hsCRP found in most elderly subjects, make a suggestion that cell death in elderly favorably occurred via cell senescence rather than apoptosis.

\section{References}

1. World Health Oorganization. Obesity: preventing and managing the global epidemic. Report of a WHO Consultation (WHO Technical Report Series 894). Geneva: World Health Organisation; 2000.

2. Badan Penelitian dan Pengembangan Kesehatan Departemen Kesehatan Republik Indonesia. Riset Kesehatan Dasar 2013. Jakarta: Kementrian Kesehatan RI; 2013.

3. Maury E, Ehala-Aleksejev K, Guiot Y, Detry R, Vandenhooft A, Brichard SM. Adipokines oversecreted by omental adipose tissue in human obesity. Am J Physiol Endocrinol Metab. 2007; 293: E65665.

4. Zvonic S, Lefevre M, Kilroy G, Floyd ZE, DeLany JP, Kheterpal I, et al. Secretome of primary cultures of human adipose-derived stem cells: modulation of serpins by adipogenesis. Mol Cell Proteomics. 2007; 6: 18-28.

5. Itariu B, Stulnig T. Obesity, insulin resistance and inflammaging. Inflamm Adv Age Nutr. 2014; 1: 157-64.

6. Libby P, Ridker PM, Hansson GK. Inflammation in atherosclerosis: from pathophysiology to practice. J Am Coll Cardiol. 2009; 54: 2129-38.

7. Shrivastava AK, Singh HV, Raizada A, Singh SK. C-reactive protein, inflammation and coronary heart disease. The Egyptian Heart Journal. 2015; 67: 89-97.

8. Franceschi C, Campisi J. Chronic inflammation (inflammaging) and its potential contribution to age-associated diseases. J Gerontol A Biol Sci Med Sci. 2014; 69: S4-9.

9. Campisi J, d'Adda di Fagagna F. Cellular senescence: when bad things happen to good cells. Nat Rev Mol Cell Biol. 2007; 8: 72940.

10. Palmer AK, Kirkland JL. Aging and adipose tissue: potential interventions for diabetes and regenerative medicine. Exp Gerontol. 2016; 86: 97-105.

11. Tchkonia T, Morbeck DE, Zglinicki T, Deursen J, Lustgarten J, Scrable H, et al. Fat tissue, aging, and cellular senescence. Aging Cell. 2010; 9: 667-84.

12. Muñoz-Espín D, Serrano M. Cellular senescence: from physiology to pathology. Nat Rev Mol Cell Biol. 2014; 15: 482-96.

13. Campisi J. Senescent cells, tumor suppression, review and organismal aging: good citizens, bad neighbors. Cell. 2005; 120: 513-22.

14. Schafer MJ, White TA, Evans G, Tonne JM, Verzosa GC, Stout MB, et al. Exercise prevents diet-induced cellular senescence in adipose tissue. Diabetes. 2016; 65: 1606-15.

15. Charan J, Biswas T. How to calculate sample size for different study designs in medical research? Indian J Psychol Med. 2013; 35:121-6.

16. Ahmadi-Abhari S, Luben RN, Wareham NJ, Khaw KT. Distribution and determinants of C-reactive protein in the older adult population: European Prospective Investigation into Cancer-Norfolk study. Eur J Clin Invest. 2013; 43: 899-911.

17. Puzianowska-Kuźnicka M, Owczarz M, Wieczorowska-Tobis K, Nadrowski P, Chudek J, Slusarczyk P, et al. Interleukin-6 and C-reactive protein, successful aging, and mortality: the PolSenior study. Immun Ageing. 2016; 13: 21. doi: 10.1186/s12979-0160076-x.

18. Freund A, Orjalo AV, Desprez PY, Campisi J. Inflammatory networks during cellular senescence: causes and consequences. Trends Mol Med. 2010; 16: 238-46.

19. Tchkonia T, Zhu Y, Van Deursen J, Campisi J, Kirkland, JL. Cellular senescence and the senesen secretory phenotype: therapeutic opportunities. J Clin Invest. 2013; 123: 966-72. 